\title{
Utilization of sludge as brick materials
}

\author{
Chih-Huang Weng ${ }^{\mathrm{a}}$, Deng-Fong Lin ${ }^{\mathrm{a}}$, Pen-Chi Chiang ${ }^{\mathrm{b}, *}$ \\ ${ }^{a}$ Department of Civil Engineering, I-Shou University, Ta-Hsu Hsiang, Kaohsiung County 840, Taiwan, ROC \\ ${ }^{\mathrm{b}}$ Graduate Institute of Environmental Engineering, National Taiwan University, Taipei 106, Taiwan, ROC
}

\begin{abstract}
Bricks manufactured from dried sludge collected from an industrial wastewater treatment plant were investigated. Results of tests indicated that the sludge proportion and the firing temperature were the two key factors determining the brick quality. Increasing the sludge content results in a decrease of brick shrinkage, water absorption, and compressive strength. Results also showed that the brick weight loss on ignition was mainly attributed to the organic matter content in the sludge being burnt off during the firing process. With up to $20 \%$ sludge added to the bricks, the strength measured at temperatures 960 and $1000{ }^{\circ} \mathrm{C}$ met the requirements of the Chinese National Standards. Toxic characteristic leaching procedure (TCLP) tests of brick also showed that the metal leaching level is low. The conditions for manufacturing good quality bricks is $10 \%$ sludge with $24 \%$ of moisture content prepared in the molded mixtures and fired at $880-960{ }^{\circ} \mathrm{C}$.
\end{abstract}

(c) 2002 Elsevier Science Ltd. All rights reserved.

Keywords: Brick; Compressive strength; Clay; Metal leaching; Sludge; Utilization

\section{Introduction}

In Taiwan, the annual sludge (dewatered) production from 34 industrial wastewater treatment plants is approximately 0.67 million tons. While sanitary landfills are commonly used for disposal of sludge in Taiwan, rapid urbanization has made it increasingly difficult to find suitable landfill sites (Lin and Weng, 2001). Utilization of sludge as an addition to construction and building material including building bricks, lightweight artificial aggregates, and cement-like materials is a winwin strategy because it not only converts the wastes into useful materials but it also alleviates the disposal problems. The prospective benefits of using sludge or sludge ash as the brick or tile additive include immobilizing heavy metals in the fired matrix, oxidizing organic matter and destroying any pathogens during the firing process, and reducing the frost damage based on the results of several full or bench scale studies (Alleman and Berman, 1984; Tay, 1987; Trauner, 1991; Alleman et al., 1990; Okuno and Takahashi, 1997;

*Corresponding author. Tel.: +886-7-657-8957; fax: +8867-657-7461.

E-mail address: chweng@isu.edu.tw (C.-H. Weng).
Wiebusch and Seyfried, 1997; Tay and Show, 1999; Weng and Lin, 2000; Lin and Weng, 2001). Nevertheless, utilization of sludge as a building material in Taiwan has not yet been a productive reality because the legal approval and public acceptance in this regard are not yet overcome.

In this study, the suitable conditions of using dried sludge in manufacturing of bricks under the criteria of Chinese National Standards (CNS) were investigated. The influence of sludge proportion in the raw materials, the temperature in relating to the brick qualities, and metal leach ability were examined.

\section{Material and methods}

The filter press dewatered and oven-dried sludge samples were obtained from a local industrial wastewater treatment plant. The dried sludge samples were taken from the outlet of a dryer which burnt 1 ton of dewatered sludge at $250{ }^{\circ} \mathrm{C}$ for $2 \mathrm{~h}$. A clay sample of normal bricks was obtained from a local brick manufacturing plant. Table 1 shows the sludge and clay characteristics and their metal content. In general, the dried sludge has a higher heavy metal content than that of the dewatered sludge and clay. The dried sludge was 
Table 1

Characteristics of sludge and clay

\begin{tabular}{|c|c|c|c|}
\hline Characteristics & Dewatered sludge & Dried sludge & Clay \\
\hline $\mathrm{pH}$ & 7.19 & 7.27 & 8.09 \\
\hline Density $\left(\mathrm{g} / \mathrm{cm}^{3}\right)$ & 1.16 & 1.75 & 2.52 \\
\hline $\begin{array}{l}\text { Volatile matter (combusted at } \\
\left.550 \pm 50{ }^{\circ} \mathrm{C} \text { for } 3 \mathrm{~h}\right)(\%)\end{array}$ & 56.9 & 61.3 & 5.9 \\
\hline Moisture content $(\%)$ & 84.1 & 41.0 & 1.4 \\
\hline $\begin{array}{l}\text { Loss on ignition (combusted at } \\
\left.800 \pm 50{ }^{\circ} \mathrm{C} \text { for } 3 \mathrm{~h}\right)(\%)\end{array}$ & 94.6 & 76.6 & 7.9 \\
\hline \multicolumn{4}{|l|}{$\operatorname{Metals}(\mathrm{mg} / \mathrm{kg})$} \\
\hline $\mathrm{Cd}$ & 3 & 5 & $<0.1$ \\
\hline $\mathrm{Cr}$ & 537 & 1713 & 16 \\
\hline $\mathrm{Cu}$ & 29 & 212 & 85 \\
\hline Co & 10 & 24 & 5 \\
\hline $\mathrm{Fe}$ & 5265 & 18070 & 8530 \\
\hline $\mathrm{Ni}$ & 167 & 1131 & 20 \\
\hline $\mathrm{Pb}$ & 3 & 35 & $<0.1$ \\
\hline $\mathrm{Zn}$ & 264 & 628 & 98 \\
\hline
\end{tabular}

directly used as a clay substitute without further treatment.

In the brick molding process, different sludge proportions were mixed with ground clay using a crushing machine. Because water content is an important factor affecting the quality of the brick, tests including specific surface area (Blaine air permeability method), compaction, and Atterberg limits were conducted first to obtain the plastic nature of the sludge-clay mixtures and to determine the optimum moisture content (OMC) in the brick manufacturing process. Using this OMC, the mixtures with various proportions of sludge and clay were prepared in batches. A vacuum machine was used to expel the air from the mixture to avoid cracking in the firing process. The mixtures were then introduced into a series of brick molds (length $230 \mathrm{~mm}$, width 110 $\mathrm{mm}$, and thickness $60 \mathrm{~mm}$ ). Sludge free mixtures were also made as reference. After a 24-h maturation followed by another $24-\mathrm{h} 103{ }^{\circ} \mathrm{C}$ oven-dry period, the molded mixtures (body) were fired in a combustion chamber at the temperature ranging from 880 to $1000{ }^{\circ} \mathrm{C}$ for $6 \mathrm{~h}$. As required by the CNS (1999) standards for building bricks, the produced bricks then underwent a series of tests including firing shrinkage, weight loss on ignition, water absorption, bulk density, and compressive strength to determine the quality of bricks (Table 2). Following criteria evaluation, the tests of toxic characteristic leaching procedure (TCLP) as described in ROC-EPA (1997) were performed to investigate the leachability of metals from bricks made from sludge.

\section{Results and discussion}

\subsection{Specific surface area of clay-sludge mixtures}

The results of specific surface area obtained for the mixtures are shown in Table 3. The specific surface area of sludge is almost the same order of magnitude as for clay, 0.51 and $0.564 \mathrm{~m}^{2} / \mathrm{g}$, respectively. As the amount of sludge increases, the specific surface area of the mixture increases proportionally. The higher specific surface area of the mixture indicates the need for more water being used in the brick molding processes. Thus, when a rather high amount of sludge is applied in replacing clay, the water requirement in the brick making process is expected to be higher than that of clay alone.

Table 2

CNS (1999) brick criteria

\begin{tabular}{lrr}
\hline Inspection item & 1st-class brick & 2nd-class brick \\
\hline Bulk density $\left(\mathrm{g} / \mathrm{cm}^{3}\right)$ & $1.8 \sim 2.0$ & $1.8 \sim 2.0$ \\
Firing shrinkage $(\%)$ & 8, maximum & 8, maximum \\
Weight loss on ignition $(\%)$ & 15, maximum & 15, maximum \\
Water absorption $(\%)$ & 15, maximum & 19, maximum \\
Compressive strength $\left(\mathrm{kg} / \mathrm{cm}^{2}\right)$ & 150, minimum & 100, minimum \\
\hline
\end{tabular}


Table 3

Effect of sludge proportion on the specific surface area and the plastic index of the mixtures

\begin{tabular}{|c|c|c|c|c|c|c|}
\hline Sludge proportion ( $\%$ by weight) & 0 & 10 & 20 & 30 & 40 & 100 \\
\hline Specific surface area $\left(\mathrm{m}^{2} / \mathrm{g}\right)$ & 0.51 & 0.514 & 0.521 & 0.53 & 0.532 & 0.564 \\
\hline Optimum moisture content (\%) & 23 & 24 & 26 & 29 & 33 & - \\
\hline Liquid limit (\%) & 38 & 39 & 41 & 45 & 46 & - \\
\hline Plastic limit $(\%)$ & 20 & 22 & 25 & 30 & 33 & - \\
\hline Plasticity index & 18 & 17 & 16 & 15 & 13 & - \\
\hline
\end{tabular}

\subsection{Compaction test and Atterberg's tests of clay- sludge mixtures}

A standard AASHTO (1982) compaction test was used to determine the $\mathrm{OMC}$ which is an important factor affecting the properties of brick. The OMC of a mixture was based on the moisture requirement in which maximum bonding among the mixture particles is retained. The test results show that the OMC is $23 \%$ for clay mixture. Increasing the sludge proportions in the mixture resulted in an increase of OMC. The effect of moisture on the pulverized material's plastic behavior is demonstrated in accordance with the Atterberg Limits test (Wray, 1985). The results of Atterberg's tests of sludgeclay mixtures indicate that the value of plastic limit is inversely proportional to the amount of sludge in the brick. A plastic limit value of 18 for clay alone shows the clay can be classified as a low plasticity material. The plastic limit values shown in Table 3 indicate that up to $30 \%$ of sludge can be applied into brick without losing its plastic behavior.

\subsection{Brick water absorption}

Water absorption is a key factor affecting the durability of brick. The less water infiltrates into brick, the more durability of the brick and resistance to the natural environment are expected. Thus, the internal structure of the brick must be intensive enough to avoid the intrusion of water. The determination of water absorption was done using the procedures as described in CNS (1999). Fig. 1 shows the results of the test for different proportions of sludge in the mixture fired at three temperatures. Fig. 1 shows that the water absorption for the bricks increases with increased sludge addition and decreased firing temperature, thereby decreasing its weathering resistance. The previously reported plastic limit values have revealed that the addition of sludge lowers the plastic nature of the mixture and also decreases the bonding ability of the mixture. When the mixture contains a rather higher amount of sludge, the adhesiveness of the mixture decreases, but the internal pore size of the brick increases. As a result, the quantity of

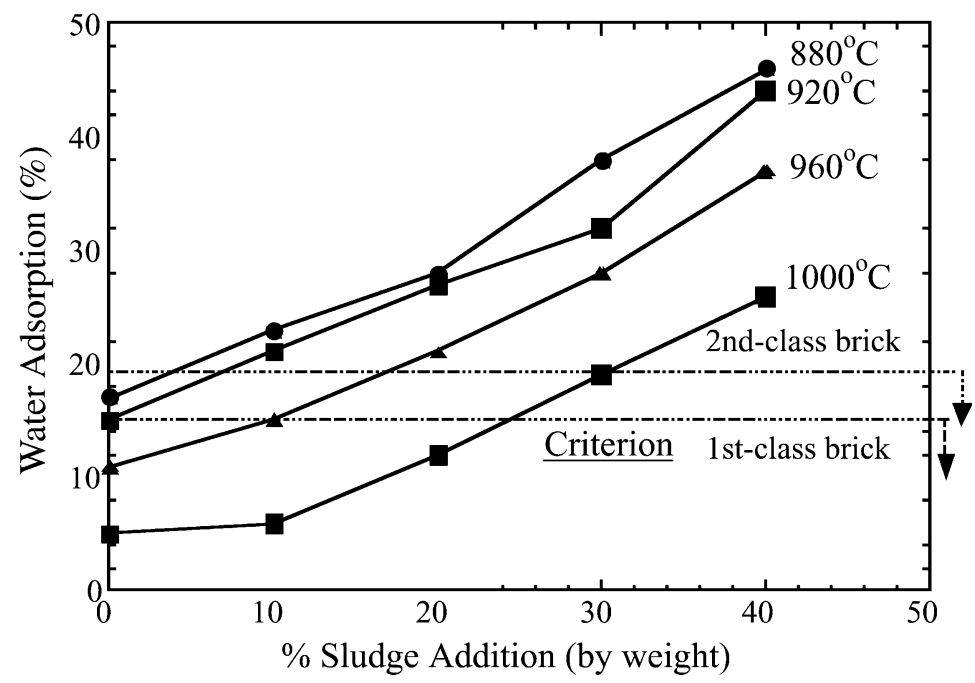

Fig. 1. The water absorption of bricks. 


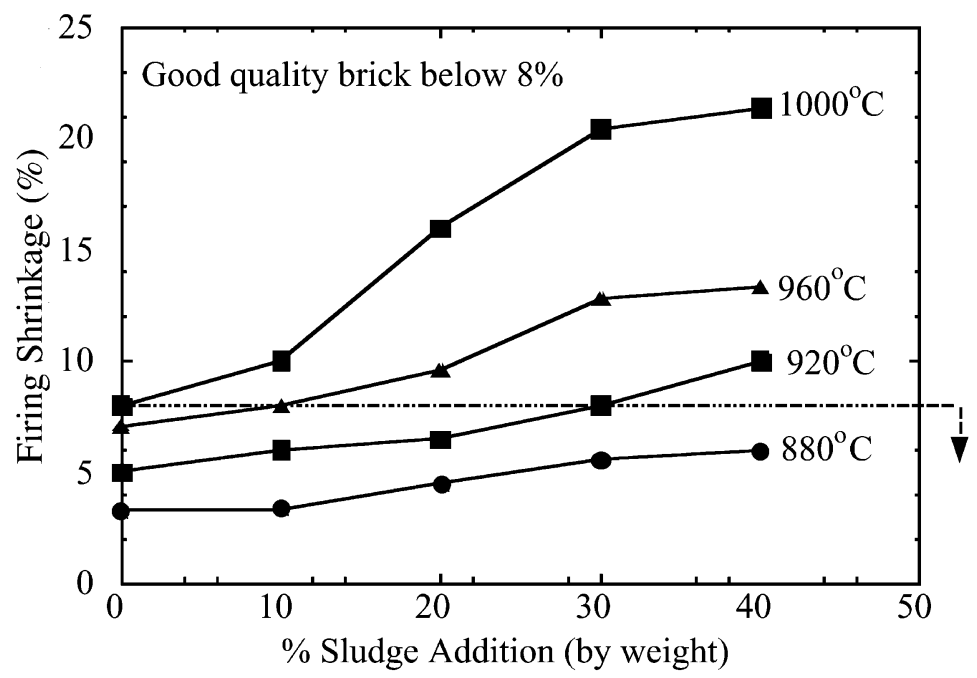

Fig. 2. The brick firing shrinkage.

absorbed water increases. As shown in Fig. 1, when the mixture contains less than $15 \%$ sludge and is fired at a temperature higher than $960{ }^{\circ} \mathrm{C}$, the percentage of absorbed water in the produced brick should lie in the 1 st class category. With $30 \%$ sludge in replacement of clay and fired at $1000{ }^{\circ} \mathrm{C}$, the brick produced in this condition meets the 2 nd class brick water absorption criteria.

\subsection{Brick firing shrinkage}

The quality of brick can be further assured according to the degree of firing shrinkage. Normally, a good quality of brick exhibits a shrinkage below 8\%. As shown in Fig. 2, the percentage of shrinkage increases with the increasing sludge addition. As the swellability and the organic content of the sludge are much higher than those of clay, the addition of sludge in the mixture should enlarge the degree of firing shrinkage. As a result, the quality of a brick is downgraded. The firing temperature is another important parameter affecting the degree of shrinkage. In general, increasing the temperature results in an increase of shrinkage (Fig. 2). Thus, the proportion of sludge in the mixture and the firing temperature are the two key factors to be controlled to minimize the shrinkage in the firing process.

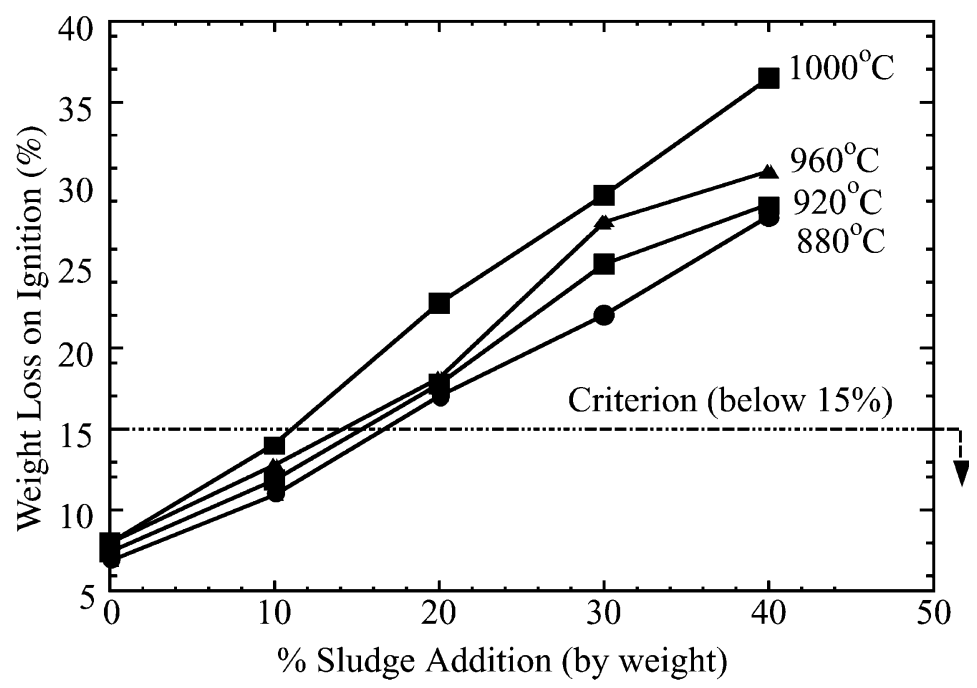

Fig. 3. The weight loss on ignition of bricks. 


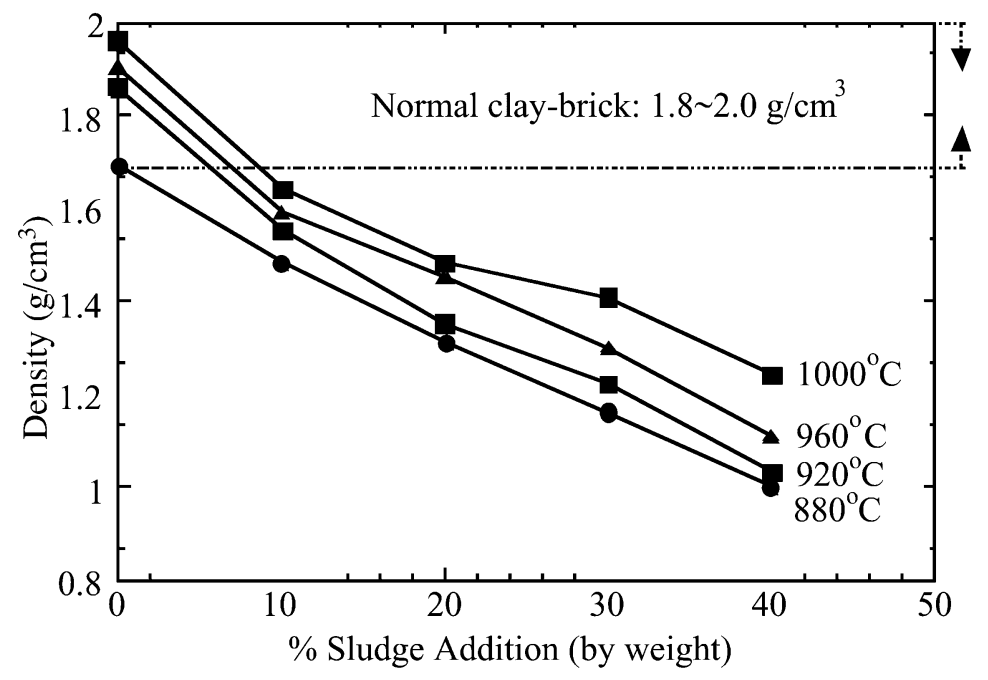

Fig. 4. The particle density of bricks.

\subsection{Brick weight loss on ignition}

Fig. 3 shows that increasing the sludge proportion and temperature resulted in increases in brick weight loss on ignition. The weight loss criterion for a normal clay brick is $15 \%$. With less than $10 \%$ sludge addition, the produced bricks all meet the criteria. Visual observation showed that an uneven surface was found for the sludge-brick. It is speculated that the formation of this unwanted surface was mainly due to the organic component burnt off during the firing process. For a normal clay brick, the loss of weight after firing at $800{ }^{\circ} \mathrm{C}$ is mainly attributed to the organic matter content in clay.
However, upon the addition of sludge in the mixture, the loss of weight apparently increased because the contribution of organic matter loss from sludge. Furthermore, the brick weight loss on ignition also depends on the inorganic substances in both clay and sludge being burnt off during the firing process.

\subsection{Density of bricks}

The bricks made with clay normally have a bulk density of $1.8-2.0 \mathrm{~g} / \mathrm{cm}^{3}$. The measurements of particle density for different proportions of sludge fired at four temperatures are demonstrated in Fig. 4. As shown, the

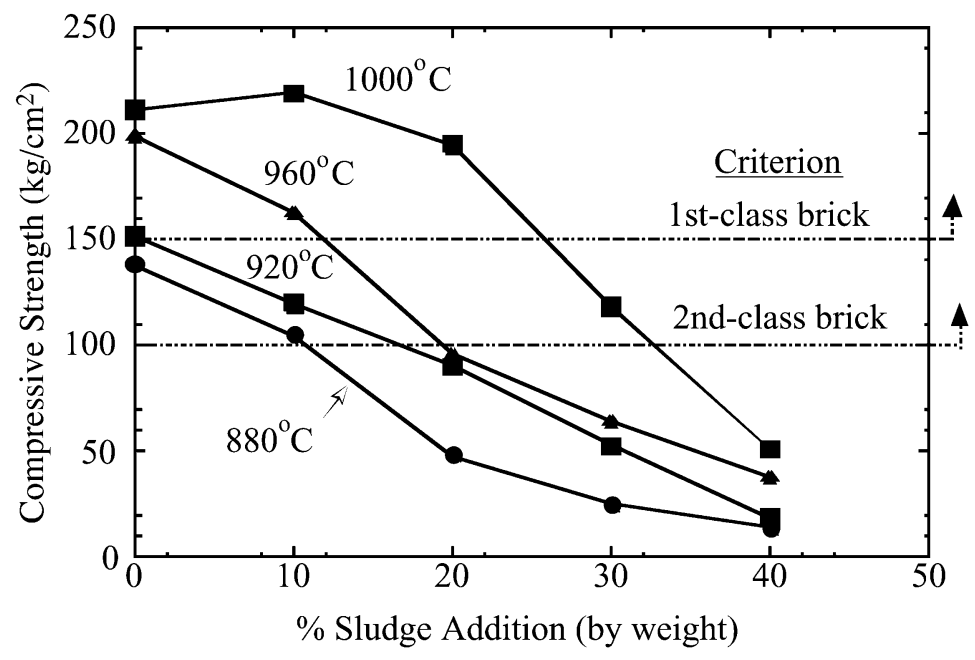

Fig. 5. The compressive strength of bricks. 
Table 4

TCLP test results of sludge and bricks

\begin{tabular}{|c|c|c|c|c|c|c|}
\hline \multirow[t]{2}{*}{ Metals } & \multirow{2}{*}{$\begin{array}{l}\text { Dried } \\
\text { sludge } \\
(\mathrm{mg} / 1)\end{array}$} & \multicolumn{4}{|l|}{ Brick } & \multirow{2}{*}{$\begin{array}{l}\text { Taiwan-EPA } \\
\text { Regulated TCLP limit } \\
(\mathrm{mg} / \mathrm{l})\end{array}$} \\
\hline & & $\begin{array}{l}880{ }^{\circ} \mathrm{C} \\
(\mathrm{mg} / 1)\end{array}$ & $\begin{array}{l}920{ }^{\circ} \mathrm{C} \\
(\mathrm{mg} / 1)\end{array}$ & $\begin{array}{l}960{ }^{\circ} \mathrm{C} \\
(\mathrm{mg} / 1)\end{array}$ & $\begin{array}{l}1000{ }^{\circ} \mathrm{C} \\
(\mathrm{mg} / \mathrm{l})\end{array}$ & \\
\hline As & 0.01 & $<0.01$ & $<0.01$ & $<0.01$ & $<0.01$ & 5 \\
\hline $\mathrm{Cd}$ & 0.01 & 0.01 & 0.01 & 0.01 & $<0.01$ & 1 \\
\hline $\mathrm{Cr}(\mathrm{VI})$ & $<0.01$ & $<0.01$ & $<0.01$ & $<0.01$ & $<0.01$ & 2.5 \\
\hline Cr(total) & 0.21 & $<0.01$ & $<0.01$ & $<0.01$ & $<0.01$ & 5 \\
\hline $\mathrm{Cu}$ & $<0.01$ & 0.04 & 0.02 & 0.01 & 0.01 & 15 \\
\hline $\mathrm{Hg}$ & $<0.01$ & $<0.01$ & $<0.01$ & $<0.01$ & $<0.01$ & 0.2 \\
\hline $\mathrm{Pb}$ & 0.07 & 0.01 & 0.01 & 0.01 & 0.01 & 5 \\
\hline $\mathrm{Zn}$ & 3.60 & 0.24 & 0.23 & 0.12 & 0.08 & 25 \\
\hline
\end{tabular}

Note: Brick containing $30 \%$ sludge.

particle density of the bricks is inversely proportional to the quantity of sludge added in the mixture. This finding is closely related to the quantity of water absorbed as demonstrated in Fig. 1. When the mixture absorbs more water, the brick exhibits a larger pore size, resulting in a light density. The firing temperature can also affect the particle density of the bricks. The results show that increasing the temperature results in an increase in particle density.

\subsection{Compressive strength of bricks}

The compressing test is the most important test for assuring the engineering quality of a building material. The results (Fig. 5) indicate that the strength is greatly dependent on the amount of sludge in the brick and the firing temperature. As shown, with up to $10 \%$ sludge added to the bricks, the strength achieved at $1000{ }^{\circ} \mathrm{C}$ can be as high as the normal clay bricks. When a $20 \%$ sludge is added in the brick, the achieved brick strength at $1000{ }^{\circ} \mathrm{C}$ lies in the scope of the 1st-class category. With up to $30 \%$ sludge added to the bricks, the strength measured at temperatures of $1000{ }^{\circ} \mathrm{C}$, met the requirements of a 2 nd class brick standard.

\subsection{TCLP test of bricks}

Results of TCLP tests are shown in Table 4. Chromium and zinc are leached from sludge, although the concentrations are much less than those of the TaiwanEPA regulated TCLP limits. Other leached metals from either dried sludge or clay are of insignificant concern. Results of leaching tests indicated that the quantities of $\mathrm{Cr}$ (total) and $\mathrm{Zn}$ leached from bricks containing 30\% sludge are all less than the original dried sludge. It is reasonable though, that the rather low metal leached resulted from rending metal in oxide form during the rather high firing temperature environment. Obviously the incineration process makes metal less leachable.

\section{Conclusions}

This work has demonstrated the suitable conditions for using dried sludge as a clay substitute to produce an engineering quality of brick. The proportion of sludge in the mixture and the firing temperature are the two key factors affecting the quality of brick. In all, the recommended proportion of sludge in brick is $10 \%$, with a $24 \%$ optimum moisture content, prepared in the molded mixtures and fired between $880{ }^{\circ} \mathrm{C}$ and $960{ }^{\circ} \mathrm{C}$ to produce a good quality brick.

\section{Acknowledgments}

This study was partly supported by the Industrial Development Bureau, Ministry of Economic Affairs of Republic of China. The findings do not necessarily represent the endorsement of this agency.

\section{References}

AASHTO, 1982. AASHTO T-99 standard test methods for moisture-density relations of soils and soil-aggregate mixtures using $5.5 \mathrm{lb}$ rammer and 12 in drop. Standard Specifications for Highway Materials and Methods of Sampling and Testing, Part II. American Association of State Highway and Transportation Officials, Washington, DC.

Alleman, J.E., Berman, N.A., 1984. Constructive sludge management: biobrick. J. Environ. Eng. 110 (2), 301-311.

Alleman, J.E., Bryan, E.H., Stumm, T.A., 1990. Sludgeamended brick production: applicability for metal-laden residues. Water Sci. Technol. 22 (12), 309-317.

Chinese National Standards (CNS), 1999. CNS1127 method of test for general types of bricks for building. CNS Catalog, R3042. Ceramic Industry, Pottery Wares, Bureau of Stan- 
dards, Metrology and Inspection Ministry of Economic Affairs, Republic of China.

Lin, D.F., Weng, C.H., 2001 Use of sewage sludge ash as brick material, J. Environ. Eng. 127(10), October issue. 922-927.

Okuno, N., Takahashi, S., 1997. Full scale application of manufacturing bricks from sewage. Water Sci. Technol. 36 (11), 243-250.

Republic of China-Environmental Protection Agency (ROCEPA), 1997. Methods for Waste Analysis NIEA-R201.10T/ NIEA-R208.00T. (in Chinese).

Tay, J-H., 1987. Bricks manufacture from sludge. J. Environ. Eng. 113 (2), 278-283.

Tay, J.-H., Show, K.-Y., 1999. Constructive sludge disposal option converting sludge into innovative civil engineering materials. Proceedings of the 7th IAWQ Asia-Pacific Regional Conference, Taipei, Taiwan. pp. 1023-1028.

Trauner, E.J., 1991. Sludge ash bricks fired to above and below ash vitrifying temperature. J. Environ. Eng. 119 (3), 506-519.

Weng, C.H., Lin, D.F., 2000. Utilization of biosolid ash as tile materials. Proceedings of Critical Technologies to the World in 21st Century: Pollution Control and Reclamation in
Process Industries, IAWQ Specialty Conference of Chemical and Petrochemical Industries Group, Beijing, PR China. pp. 142-151.

Wiebusch, B., Seyfried, C.F., 1997. Utilization of sewage sludge ashes in the brick and tile industry. Water Sci. Technol. 36 (11), 251-258.

Wray, W.K., 1985. Atterberg limits. Measuring Engineering Properties of Soil. Prentice-Hall, USA, Englewood Cliffs, NJ Chapter 4.

Chih-Huang is an Associate Professor in the Department of Civil Engineering at the I-Shou University, Taiwan. His research interests are in the areas of environmental engineering.

Deng-Fong is an Associate Professor in the Department of Civil Engineering at the I-Shou University, Taiwan. His research interests are in the areas of pavement engineering.

Pen-Chi is a Professor in the Graduate Institute of Environmental Engineering at the National Taiwan University, Taiwan. His research interests are in the areas of environmental engineering. 